\title{
Judgement for Israel: The Marriage of Wrath and Mercy in Romans 9-11
}

\author{
THOMAS P. DIXON \\ Campbell University, PO Box 1029, Buies Creek, NC 27506, USA. \\ Email:tdixon@campbell.edu
}

\begin{abstract}
Reviewing John Barclay's Paul and the Gift, Susan Eastman recognises the need for 'fuller analysis of judgment' in Paul to accompany such penetrating work on grace. The dearth of interest in wrath often perpetuates the Marcionite premise that wrath precludes mercy, a false antithesis that especially skews interpretation of Romans. This presumed opposition leads scholars to find dithering dialectic, two covenants, two Israels or contradictory fantasy in Rom 9-11. Replacing the simple binary with a thicker lens of provisional judgement clarifies Paul's argument that God strikes Israel in wrath in order to heal them.
\end{abstract}

Keywords: Paul, Romans, wrath, Israel, mercy, judgement

\section{Introduction}

'Prophecy consists in the inspired communication of divine attitudes to the prophetic consciousness', writes Abraham Heschel, and 'the divine pathos is the ground-tone of all these attitudes'. God's passionate concern for the world means that 'human actions arouse in Him joy or sorrow, pleasure or wrath', but this wrath always acts in service to divine mercy in a relation that defies the God of the philosophers. ${ }^{1}$ For Israel's prophets, ‘[a]nger and mercy are not opposites but correlatives'. ${ }^{2}$

Very few have followed Heschel to explore the intersection of wrath and mercy in the New Testament, as God's wrath is understandably an 'ungeliebte' topic of study. ${ }^{3}$ This lacuna, however, often houses the Marcionite premise that wrath and mercy are

1 A. J. Heschel, The Prophets (New York: Harper Perennial Classics, 2001) 288-9. See 'The Meaning and Mystery of Wrath', 358-82.

2 Heschel, Prophets, 364.

3 See R. Miggelbrink, Der Zorn Gottes: Geschichte und Aktualität einer ungeliebten biblischen Tradition (Freiburg: Herder, 2000). 
mutually exclusive. ${ }^{4}$ This problem is particularly acute in the study of Romans, in which Paul famously opens the body of the letter with the wrath of God (1.18). ${ }^{5}$ Paul cites ó $\gamma \eta \dot{n}$ twelve times in Romans, but scholars continue to puzzle over the relationship between this wrath and pronouncements of cosmic salvation in Christ. This tension often breaks on the exegesis of Rom 9-11, maybe the most controverted passage in Paul's corpus. ${ }^{6}$ He divides his kindred into vessels of wrath and vessels of mercy, only to claim later that all Israel will be saved. Most find Paul's argument to be at best a tortuous dialectical detour, if not contradictory fantasy.

While many commentators allow that judgement somehow moves to mercy in the Israel-Kapitel, a proper conception of God's wrath is critical for tracing Paul's logic and making a coherent case. With his own scriptural reasoning, Paul considers that divine wrath is often provisional, and Rom 9-11 describes restorative wrath on Israel that leads to mercy on those judged. After addressing the decline of modern scholarly interest in divine wrath and canvassing images of judgement in Paul's scriptures, this article will demonstrate that Israel's plight in Rom 9-11 can only be understood through an appropriately thick lens of divine wrath.

\section{The Disappearance of Wrath}

Daniel Walker wrote in 1964 of a 'decline of hell' in theological teaching beginning in the seventeenth century, ${ }^{7}$ and there has been a corresponding decline in the study of wrath in Paul. Friedrich Schleiermacher was foundational in this modern dismissal, denying that wrath or retributive punishment exists in God's justice $^{8}$ and asserting that the doctrine of God's wrath is neither grounded

4 Tertullian claims that Marcion confines emotions to Judaism's inferior Creator God; the God of Jesus Christ is free from anger and the impulse to chastise (animadversionis). See Tertullian, Adversus Marcionem, 2 vols. (ed. and trans. E. Evans; Oxford: Clarendon: 1972), 1.26.2. Due to Irenaeus (Haer. 1.27.1-2), some trace Marcion's views back to the Stoicism of his mentor, but the evidence for Marcion's dependence on Cerdo is sketchy (see J. M. Lieu, Marcion and the Making of a Heretic: God and Scripture in the Second Century (Cambridge: Cambridge University Press, 2015) 33-5). Philo and others were wrestling with the tension of mercy and judgement in scripture long before Marcion (see Lieu, Marcion, 343-6), but Tertullian does insist that Marcion was the first to introduce a god opposed to the Creator 'whose sole attribute was goodness' (Tertullian, Praescr. 34, cited in Evans, Tertullian, xiii).

5 Marcion apparently ascribes the wrath in Rom 1.18 to the Creator God's anger against a rival god. In any case, Tertullian claims that Marcion, as with Luke and other texts, has excised whole passages from Romans in the 'Apostolikon' (Tertullian, Marc. 5.13).

6 See 'Conclusion' below.

7 D. P. Walker, The Decline of Hell: Seventeenth-Century Discussions of Eternal Torment (Chicago: University of Chicago Press, 1964).

8 F. Schleiermacher, The Christian Faith, vols. I and II. A New Translation and Critical Edition (trans. T. N. Tice, C. L. Kelsey and E. Lawler; ed. C. L. Kelsey and T. N. Tice; Louisville, KY: Westminster John Knox, 2016) 530-1 (\$84.3). Opposition to divine wrath, especially by 
in Christianity nor even 'a proper doctrine'. ${ }^{9}$ A certain historicism drives Schleiermacher's belief: 'now is the time to summon humanity' against the 'false fear of God's wrath'. ${ }^{10}$ Paul only references God's wrath as an accommodation to his Jewish audience, who still held elementary, Old Testament notions of God as an angry deity. ${ }^{11}$ Adolf von Harnack famously avers that 'Marcion was the only Gentile Christian who understood Paul, and even he misunderstood him', ${ }^{12}$ going so far as to support the rejection of the Old Testament in nineteenth-century Christianity. ${ }^{13}$ Part of Harnack's justification for decanonising the Jewish scriptures seems to have stemmed from the putative antithesis between judgement and mercy: 'Marcion proclaimed with a splendid assurance that the loving will of Jesus (and, that is, of God) does not judge, but comes to our aid. ${ }^{14}$ In his 1932 Romans commentary, C. H. Dodd contends that Paul 'retains the concept of the "the Wrath of God" ... to describe an inevitable process of cause and effect in a moral universe'. ${ }^{15}$ The picture of Rom 1.18-32 describes a 'natural process of cause and effect, and not ... the direct act of God', ${ }^{16}$ while the wrath in 12.19 'means the principle of retribution inherent in a moral universe'. ${ }^{17}$ Hence, anticipated by Schleiermacher and followed by others, ${ }^{18}$ Dodd sees no real wrath in Paul's God.

The decades since Stendahl and Sanders ${ }^{19}$ have witnessed many studies of judgement in Paul, but these primarily focus on the mechanism of justification

Schleiermacher and Ritschl, marked a pivotal transition in the rise of Liberal Theology (S. B. Murray, Reclaiming Divine Wrath: A History of a Christian Doctrine and its Interpretation (New York: Peter Lang, 2011) 171-9).

9 F. Schleiermacher, 'The Wrath of God', Servant of the Word: Selected Sermons of Friedrich Schleiermacher (trans. D. De Vries; Philadelphia: Fortress, 1987) 152-65, at 153.

10 Schleiermacher, 'Wrath of God', 164-5.

11 Schleiermacher, 'Wrath of God', 154. Retributive judgement is a 'primal necessity' that is associated with a 'lower stage of development' where gods are susceptible to emotions; such a picture cannot be accepted 'today' (Christian Faith, 530-1 (\$84.3)).

12 A. von Harnack, History of Dogma, vol. I (trans. N. Buchanan; Williams \& Norgate: London, 1894) 89.

13 A. von Harnack, Marcion: The Gospel of the Alien God (trans. J. E. Steely and L. D. Bierma; Durham, NC: Labyrinth, 1990) 134.

14 Harnack, Marcion, 143.

15 C. H. Dodd, The Epistle of Paul to the Romans (MNTC; New York: Harper, 1932) 23.

16 Dodd, Romans, 55.

17 Dodd, Romans, 204. Cf. Schleiermacher, Christian Faith, 527-8 (§84.3): all punishments are 'grounded in divine creative and world-ordering causality' and in 'the interconnected process of the world'.

18 See especially A. T. Hanson, The Wrath of the Lamb (London: SPCK, 1957) 84-5, 92; also G. H. C. MacGregor, 'The Concept of the Wrath of God in the NT', NTS 7 (1961) 101-9.

19 See especially K. Stendahl, 'The Apostle Paul and the Introspective Conscience of the West', HTR 56 (1963) 199-215; idem, Paul among Jews and Gentiles and Other Essays (London: 
in light of a new perspective on Judaism, or on the puzzle of fitting salvation by grace together with passages implying judgement by works. ${ }^{20}$ There is little treatment of the character of God's wrath in relation to mercy, and the relation is often viewed as a simple opposition. Even someone as starkly opposed to Marcion's programme as Richard Hays can pit 'severe retributive justice' against 'God's gracious saving power', the latter constituting righteousness in Rom 3.21. ${ }^{21}$ In Rom 9-11, '[o]nly the presence of the seed distinguishes Israel from the archetypal targets of God's wrath'. ${ }^{22}$ Interpreters in the 'apocalyptic Paul' camp often speak of God's judgement, but they rarely probe God's wrath on human beings. ${ }^{23}$ More typical is reflection on God's judgement of Sin, Death or the world. For instance, Martinus de Boer concludes that for Paul ' $t$ t] he final judgment entails God's defeat and destruction of cosmic evil forces' ${ }^{24}$ Douglas Campbell insists that 'there is no retributive character' at all in Paul's theology of God. ${ }^{25}$ Paul's Gospel 'speaks of a

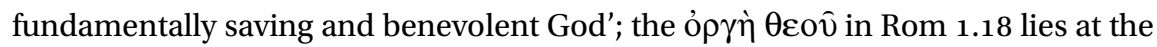
centre of the Teacher's gospel (not Paul's), and 'responds to all actions retributively, and to sinful actions punitively'. These pictures 'could not, in this sense,

SCM, 1976); E. P. Sanders, Paul and Palestinian Judaism: A Comparison of Patterns of Religion (Philadelphia: Fortress, 1977).

20 L. Mattern explores the logic of judgement on Christians (Das Verständnis Gerichtes bei Paulus (Zürich: Zwingli, 1966): see 25-9, 137-9). C. Roetzel emphasises the corporate dimension of judgement in Paul (Judgement in the Community: A Study of the Relationship between Eschatology and Ecclesiology in Paul (Leiden: Brill, 1972): see 80-1, 175-9). E. Synofzik concludes that Paul's judgement texts serve a parenetic rather than substantial part of his theology, and remedial wrath is not of concern (Die Gerichts- und Vergeltungsaussagen bei Paulus: Eine traditionsgeschichtliche Untersuchung (GTA 8; Gottingen: Vandenhoeck \& Ruprecht, 1977): e.g. 105). Since Sanders and in close conversation with him, see K. L. Yinger, Paul, Judaism, and Judgment according to Deeds (Cambridge: Cambridge University Press, 1999); K. McFadden, Judgment according to Works in Romans: The Meaning and Function of Divine Judgment in Paul's Most Important Letter (Minneapolis: Fortress, 2013); C. Stettler, Das Endgericht bei Paulus: Framesemantische und exegetische Studien zur paulinischen Eschatologie und Soteriologie (WUNT 371; Tübingen: Mohr Siebeck, 2017): see $44-7$.

21 R. B. Hays, Echoes of Scripture in the Letters of Paul (New Haven: Yale University Press, 1989) 52. 22 Hays, Echoes, 68.

23 J. L. Martyn does not address God's wrath in Theological Issues in the Letters of Paul (London: T\&T Clark, 1997), and says almost nothing of judgement; when he does, it typically relates to the Teachers' theology of judgement $(16,299)$.

24 M. C. de Boer, Galatians: A Commentary (NTL; Louisville, KY: Westminster John Knox, 2011) 32. De Boer cites Rom 1.18 as describing God's 'judgment upon "this world"' (Galatians, 81; see 34). See also idem, The Defeat of Death: Apocalyptic Eschatology in 1 Corinthians 15 and Romans 5 (JSNTSup 22; Sheffield: JSOT, 1988).

25 D. A. Campbell, The Deliverance of God: An Apocalyptic Rereading of Justification in Paul (Grand Rapids: Eerdmans, 2009) 706 (emphasis original). 
be more different. And only one is thoroughly rooted in the implications of the Christ event'. ${ }^{26}$ Taking cues from Rom 5, Susan Eastman emphasises God's condemnation of the Sin that Christ absorbs in his participation in human flesh and death. ${ }^{27}$ The liberative pictures in Rom 5 and 8 apparently overshadow the judgement on humanity depicted in Rom 1.18-3.20. ${ }^{28}$

John Barclay has done much to correct the notion that grace cannot involve punishment, ${ }^{29}$ but neither he nor his protégés in the Durham 'grace' school ${ }^{30}$ have yet probed what wrath is for Paul in Romans and how it might co-exist with mercy. In her review of Barclay's groundbreaking work on grace, Susan Eastman calls for a corresponding re-examination of judgement in Paul. ${ }^{31}$

In recent study on Paul, God's wrath sometimes appears on the periphery, but it has not been the centre of sustained examination. For many it seems that God's mercy cannot co-exist with wrath, and Paul is inconsistent when he speaks of both, as in Rom 9-11. ${ }^{32}$ This is precisely the putative inconsistency that the current article contests, and images of divine wrath in Paul's own scriptures shed clarifying light on the problem.

\section{The Scriptural Background of God's Wrath in Romans}

Paul's initial, driving image for God's wrath as handing people over (Rom $1.24,26,28)$ would have rung true to Jewish ears familiar with Israel's traditions. God delivers the disobedient (often Israel) to enemies repeatedly in the Jewish literature circulating in Paul's time, most especially in that which he considered

26 Campbell, Deliverance, 706 (emphasis original). Elsewhere Campbell does concede that divine wrath or displeasure could stem from benevolence, and that Paul does envision punitive action from God at various points: the motif of divine wrath 'is undeniably present' in Paul (92).

27 S. G. Eastman, 'Apocalypse and Incarnation: The Participatory Logic of Paul's Gospel', Apocalyptic and the Future of Theology (ed. J. Davis and D. Harink; Eugene, OR: Wipf \& Stock, 2012) 165-82, at 176.

28 Eastman, 'Apocalypse', 173-4.

29 J. M. G. Barclay, Paul and the Gift (Grand Rapids: Eerdmans, 2015) 70-1, 81-5 and esp. 465-6.

30 E.g. J. A. Linebaugh, God, Grace, and Righteousness in Wisdom of Solomon and Paul's Letter to the Romans (NovTSup 152; Leiden: Brill, 2013); K. B. Wells, Grace and Agency in Paul and Second Temple Judaism: Interpreting the Transformation of the Heart (NovTSup 157; Leiden: Brill, 2015); O. McFarland, God and Grace in Philo and Paul (NovTSup 164; Leiden: Brill, 2016).

31 S. Eastman, 'Grace and Transformation' (review of John Barclay, Paul and the Gift), Marginalia: Los Angeles Review of Books (9 May 2016), online at http://marginalia.lareviewofbooks.org/gracetransformation-susan-eastman/.

32 Campbell is not alone when he finds it 'questionable how consistent these commitments within Paul [to divine punitive action] are with the basic insights of his gospel' (Deliverance, 94; but cf. 929-30). 
scripture. The relevant examples are too many to enumerate here, so a few will suffice. In Lev $26.25^{33}$ God will avenge his covenant by sending death and handing over $(\pi \alpha \rho \alpha \delta i \delta \omega \mu \mathrm{l})$ transgressors into enemy hands. At the beginning of Judges, 'the Lord was very angry with Israel and gave them over $[\pi \alpha \rho \alpha \delta i \delta \omega \mu \mathrm{l}]$ into the hands of the plunderers' (Judg 2.14). ${ }^{34}$ God's wrath in Isa 34.2 leads him to hand people over $(\pi \alpha \rho \alpha \delta i \delta \omega \mu)$ to slaughter. Psalm 105.40-1 (106 MT) reads: 'The Lord was angered in wrath and ... delivered his people $[\pi \alpha \rho \alpha \delta i \delta \omega \mu \mathrm{l}]$ into the hands of their enemies'. In $2 \mathrm{Chr} 6.36$, Solomon says of God: 'If they sin against you (for there is no one who does not $\sin$ ) and you strike them [MT "are angry"] and hand them over [ $\pi \alpha \rho \alpha \delta i \delta \omega \mu 1]$ before the enemies ...'35

There is another facet of God's wrath in Romans, however, that also reflects Paul's scriptures: namely, that wrath is often temporary and directed towards mercy. As noted above, Heschel has persuasively demonstrated how prevalent this notion is in the prophetic literature (and beyond), arguing that restorative wrath is central to the divine pathos that lies at the heart of prophetic theology. ${ }^{36}$ God's wrath is not divorced from mercy but serves it as a provisional measure: 'Anger and mercy are not opposites but correlatives.' ${ }^{37}$ This feature of wrath may not be quite as ubiquitous as Heschel claims, in the prophets or elsewhere, but across the scriptures wrath can be temporary and even remedial, and this is often expressed with 'chastening' language. ${ }^{38}$

Again, only a few examples of temporary and/or remedial wrath must suffice, but the theme pervades the Old Testament. Restorative punishment is especially prominent in the most cited book in Romans, Isaiah. ${ }^{39}$ After describing the death and destruction God sends upon Israel in anger, Isaiah claims that the people did not turn to seek the Lord until they were struck (9.7-12). With the refrain that 'his anger has not been diverted' (see 9.11) and threats of wrath both through and

33 All references are to the LXX unless otherwise noted.

34 All translations are mine unless otherwise noted.

35 Similar images also appear outside of the MT canon: e.g. Bar 2.4-5; 4.6; 1 Macc 1.64; 4.30; 1 Esd 1.50. On the connection between this 'Auslieferungsformel' and wrath outside of Paul, see M. Theobald, Studien zum Römerbrief (WUNT 136; Tübingen: Mohr Siebeck, 2001) 7982. Theobald maintains that this handing over by God is a 'foretaste' of God's eschatological wrath (8o). See also B. R. Gaventa, Our Mother Saint Paul (Louisville, KY: Westminster John Knox, 2007) 114-16.

36 Heschel, The Prophets, 358-82, and passim.

37 Heschel, Prophets, 364. Heschel shares much in common with Origen (see Origen, Cels. 4.10, 71-2, 99), but Origen distances divine wrath from $\pi \alpha \dot{\theta} \theta$ o (Cels. 4.72; but cf. Hom. Ezech. 6.6).

38 Cf. Heschel's chapter on 'Chastisement' (Prophets, 238-48).

39 Not including uncertain allusions, one calculation has Paul citing Isaiah fifteen times in Romans; see J. R. Wagner, 'Isaiah in Romans and Galatians', Isaiah in the New Testament: The New Testament and the Scriptures of Israel (ed. S. Moyise and M. J. J. Menken; London: T\&T Clark, 2005) 117-32, at 117. 
against Assyria, Isa 10.4-6 introduces a confusing string of judgements ${ }^{40}$ that will whittle Israel down to a remnant (vv. 22-3, cited in Rom 9.27-8), sending dishonour upon Israel's ${ }^{41}$ honour and glory (v. 16; cf. Rom 9.21-3). These woes are characterised as sanctifying punishment: 'The light of Israel will be a fire and will sanctify him in burning fire' (Isa 10.17; cf. 1.25; 4.3-4). In the summative doxology of Isa 12, God promises, 'you will say in that day, "I will bless you, Lord, because you were angry with me and you turned away your anger and had mercy on me"' (vv. 1-2). God shockingly speaks of 'striking and healing' Egyptians in Isa 19, drawing them to return to God and receive mercy. As God judges the labourers of Ephraim in Isa 28, he will lay a trustworthy cornerstone (v. 16, cited in Rom 9.33), so that judgement will be for hope (28.17), and despite the wrath that will come (v. 21), 'you will be chastened [ $\pi \alpha 1 \delta \varepsilon v \theta \eta ் \emptyset \eta]$ by your God's judgement, and you shall rejoice' (v. 26). These images all occur before the famous turn from judgement to mercy beginning in Isa 40, after which temporary and remedial judgement continue to abound: for example, 'On account of my wrath I struck you and on account of my mercy I loved you' (60.10). ${ }^{42}$

This pattern is by no means limited to Isaiah: God's wrath is depicted as temporary or chastening throughout the law, prophets and writings. Even Lamentations speaks of God's wrath ending and turning to steadfast love (cf. Lam 3.25-33; 4.22). ${ }^{43}$ The Psalms, also cited frequently in Romans, ${ }^{44}$ are especially full of these images, as the psalmists often consider themselves to be under divine wrath that can be temporary (e.g. Pss $37 ; 73 ; 84 ; 105.40-8$ ) or remedial (77.31-8; 82.15-19; 89.10-12; 93.10-12; 118.67, 71, 75). One of the most common forms of judgement in the psalter is rejection (usually $\dot{\alpha} \pi \omega \theta \dot{\varepsilon} \omega$, a critical term for judgement in Rom 11), but there is a repeated conviction that rejection is temporary (e.g. 43.10, 24; 59.3; 73.12-23; 88.39-50). Similar provisional wrath also permeates Jewish literature outside of the MT canon. ${ }^{45}$

40 Brueggemann calls the chapter (in the MT) 'complicated and unclear ... [consisting] of a variety of fragmentary pieces that were likely accumulated over a long period of time' (W. Brueggemann, Isaiah 1-39 (WBC; Louisville, KY: Westminster John Knox, 1998) 91). The odd chapter casts Assyria in both a positive and negative light (B. S. Childs, Isaiah (OTL; Louisville, KY: Westminster John Knox, 2001) 91).

41 Isa 10.16 MT may imply Assyria as the object of punishment, but the target is not named.

42 Other instances of temporary/remedial wrath in Isaiah are manifold, but see also Isa 1.14-18, 24-5; 4.3-4; 28.23-9; 29.13-24; 30.19-20; 54.7-8; 60.10.

43 Other examples are too many to count: e.g. Exod 32.12-14; Lev 26.18-27, 41-3; Deut 30.1-3; Jer 3.12; 26.28; Ezek 43.8-11; 2 Chr 6.36-9. The first person in the Bible to be identified as an object of God's wrath is Moses, in Exod 4.14 (the wrath clearly being temporary).

44 See Wagner, 'Isaiah in Romans and Galatians', 117.

45 E.g. Pr Man 5-14; Wis 3.4-5; 12.20-2; 16.5-6; 18.20-5; Ecclus 5.6; 47.20-2; Tob 13.2-10; Bar 4.25-9; 2 Macc 5.17-20; 6.12-16; 7.33-8; 8.5; Pss. Sol. 2.24-30; 7.3-9; 18.3-7; 2 Bar. 1.4; 4.1 (cf. 81.4); 13.9-10; T. Gad 5.9-11; T. Zeb. 9.9; cf. 7.4-6; 1QS 11.9-15; 1QH 4.12-15; 9.32-4; 17.9-12, 24-5, 33-4; 19.8-9; 20.21-2, 30-1; 4Q504 1-2 ii, 8-11; 1-2 iii, 6-10. 
Paul's scriptures repeatedly depict mercy and judgement as two arms of a complex divine love. These passages do not dictate Paul's own views, and some scriptural texts do not portray divine wrath as temporary or remedial. Nonetheless, this background does provide a plausibility structure within which one should not be surprised if Paul also describes divine wrath that leads to mercy. In fact, outside Romans Paul himself signals that God's judgement can serve chastening purposes, ${ }^{46}$ even if it does not always do so. ${ }^{47}$ Such provisional wrath also emerges across Romans and provides an interpretive key to Paul's controversial account of God and Israel in Rom 9-11.

\section{Rom 9-11 as Microcosm of Rom 1-8}

Before detailed exegesis, it will be helpful to recognise an overarching resonance between Paul's argument about God and Israel in Rom 9-11 and his argument about God and all humanity in Rom 1-8. Many scholars recognise links between Rom 1-8 and 9-11, ${ }^{48}$ but none have appreciated the extent of this relation, which will prove vital for grasping Paul's logic in the latter. Closely comparing the two sections' features reveals that Rom 9-11 functions as a microcosm of Rom 1-8. The end of Rom 8 leaves one wondering, in light of this cosmic salvation: what about Israel - specifically unbelieving Israel? ${ }^{49}$ Romans $9-11$ is Paul's

46 See especially 1 Cor 3.15; 5.5; 11.27-32; 2 Cor 2.6-7; Gal 3.22-3 (cf. Rom 11.32); cf. Eph 2.3.

47 Gaventa proposes that 1 Thess 2.16, read in light of Rom 11.26, may speak of salvific wrath

(B. R. Gaventa, First and Second Thessalonians (Interpretation; Louisville, KY: Westminster John Knox, 1998) 37), yet this is far from certain. Aside from the question of whether Paul

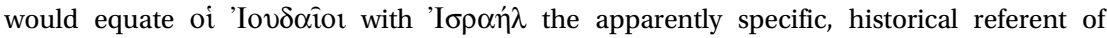
$\dot{\eta}$ ó $\gamma \eta \dot{n}$ in 1 Thess 2.16 is too elusive to impinge much on the plight of Israel in Rom 9-11, or vice versa. The aorist $\varepsilon \varphi \theta \alpha \sigma \varepsilon v$ in 1 Thess 2.16 does imply, however, that even if 1 Thess 1.10 and 5.9 both describe future judgement, ó $\rho \gamma \eta$ is not merely future in 1 Thessalonians. Gaventa's suggestion at least gains plausibility when one sees that Rom 9-11 describes a scen-

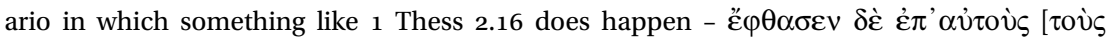

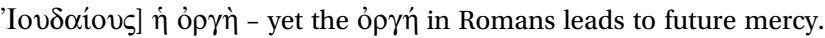

48 See H.-M. Lübking, Paulus und Israel im Römerbrief: Eine Untersuchung zu Römer 9-1 1 (EHS 23.260; Frankfurt: Lang, 1986) 21-51; D. Sänger, Die Verkündigung des Gekreuzigten und Israel: Studien zum Verhältnis von Kirche und Israel bei Paulus und im frühen Christentum (WUNT 75; Tübingen: Mohr Siebeck, 1994) 151-81; A. Reichert, Der Römerbrief als Gratwanderung: Eine Untersuchung zur Abfassungsproblematik (FRLANT 194; Göttingen: Vandenhoeck \& Ruprecht, 2001) 147-222.

49 F. J. Leenhardt finds 'une veritable nécessité logique' that propels Paul to 9-11 (L'épitre de Saint Paul aux Romains (CNT 6; Paris, Delachaux, 1957) 138). T. Tobin finds no break between Rom 8 and 9, positing a unity across Rom 8-11 (Paul's Rhetoric in its Contexts: The Argument of Romans (Peabody, MA: Hendrickson, 2004) 251-72). See also J. Piper, The Justification of God: An Exegetical and Theological Study of Romans 9:1-23 (Grand Rapids: Baker, 1993) 18. 
answer. Here Paul applies to disobedient ${ }^{50}$ Israel the trajectory of argument he has traced on the cosmic scale in chapters $1-8 .^{51}$

The major components of Paul's argument in both sections are set out in Table 1. These points clarify that God relates to disobedient Israel in Rom 9-11 in a fashion parallel with how he relates to disobedient humanity in Rom 1-8. Paul's line of argument is not always sequential, but the key points appear prominently in Rom 1-8 and 9-11:

Human disobedience/ $\rightarrow$ God's sovereignty $\rightarrow$ God's wrath $\rightarrow \quad$ God's salvation unbelief over disobedience on disobedience follows wrath

For the present purposes, the key point to recognise about the divine wrath outlined in 1.18-3.20 is that for at least some it is temporary and leads to mercy. On the terms Paul has set, ${ }^{52} 3.20$ demonstrates that everyone is unrighteous and therefore (1.18) under God's wrath, yet Paul does not imagine everyone remaining under wrath forever. At least some receive grace and salvation from wrath (5.9) through Christ, whom God 'handed over ( $\pi \alpha \rho \varepsilon \delta \delta \kappa \varepsilon v)$ for us all' (8.32), meaning that the wrath introduced at 1.18 is temporary and consonant with mercy for some. When one allows this possibility for the judgement described in Rom 9-11, these chapters cohere and mirror Rom 1-8.

\section{Wrath and Mercy in Rom 9-11}

As is the case with Rom 1-8, so in Rom 9-11 a clear grasp of Paul's logic hinges on a proper conception of divine judgement. In light of texts such as

50 Because unbelief is identified with disobedience in Rom 10.16, and the phrase 'obedience of faith' bookends the letter $(1.5 ; 16.26)$, disobedience and unbelief are inseparable for Paul.

51 If S. Stowers, for example, is correct that Paul writes to an entirely gentile audience, in which Rom 1-4 or 1-8 focus not on humanity as a whole but on gentile morality (A Rereading of Romans: Justice, Jews, and Gentiles (New Haven: Yale, 1994)), then the argument of Rom 911 would be more of a parallel to 1-8 than a microcosm, but the key points for this article would still hold. I am grateful to a perceptive reviewer for pointing this out. The present con-

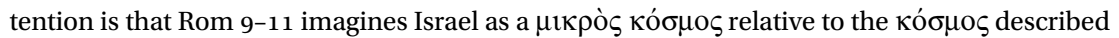
in Rom 1-8, of which Israel is part. Paul's strategy would be loosely akin to Plato's image of a literary composition resembling the кó $\sigma \mu \mathrm{\varsigma}$ (see J. A. Coulter, The Literary Microcosm: Theories of Interpretation of the Later Neoplatonists (Leiden: Brill, 1972) 95).

52 The 'righteous gentiles' in 2.13-15 are a classic conundrum, but even if these are not hypothetical and refer to Christ-believers who will fulfil the law (see 8.4; 13.8), Paul's argument in 3.920 makes it clear that no one is yet justified on the terms of 2.5-16. Not one person is righteous, for all Jews and gentiles are under sin (3.9-10). If Paul has just referred to righteous and saved (only gentile?) Christians, his claims of universal unrighteousness and vulnerability to judgement in 3.9 and 3.19-20 collapse. The opening argument climaxes at 3.20, and on the terms of 1.18-3.20 all are unrighteous and subject to wrath. 
Table 1. Comparison of Argument in Rom 1-8 and Rom 9-11

\begin{tabular}{|c|c|c|}
\hline & 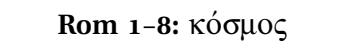 & 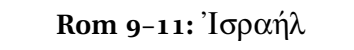 \\
\hline $\begin{array}{l}\text { (1) Human } \\
\text { disobedience/ } \\
\text { unbelief: } \\
\text { unrighteousness } \\
\text { despite law works }\end{array}$ & $1.18-32 ; 3.9-20$ & $9.2-3 ; 9.30-10.4 ; 10.16,21$ \\
\hline $\begin{array}{l}\text { (2) Not all Israel is } \\
\text { Israel: Descent does } \\
\text { not save/(breach of) } \\
\text { law produces wrath } \\
\text { But Jews have } \\
\text { special blessings }\end{array}$ & $\begin{array}{l}2.1-29 ; 4.9-16 \\
3.1-2\end{array}$ & $\begin{array}{l}9.6-13 \\
9.4-5\end{array}$ \\
\hline $\begin{array}{l}\text { (3) God's sovereignty } \\
\text { over disobedience } \\
\text { Are humans } \\
\text { culpable if God is } \\
\text { sovereign? }\end{array}$ & $\begin{array}{l}1.24-8 \\
3.5-8\end{array}$ & $\begin{array}{l}9.16-24 ; 11.7-10 \\
9.14,19-20\end{array}$ \\
\hline $\begin{array}{l}\text { (4) God's wrath on } \\
\text { disobedience }\end{array}$ & $1.18-32 ; 2.1-9 ; 3.5-6 ; 4.15$ & $9.18-23 ; 11.7-10$ \\
\hline $\begin{array}{l}\text { (5) Wrath on } \\
\text { disobedience } \\
\text { becomes mercy on } \\
\text { the disobedient } \\
\text { God turns tragedy to } \\
\text { good }\end{array}$ & $\begin{array}{l}3.21-6 ; 5.8-21 \\
5.8,16,20 ; 8.28\end{array}$ & $\begin{array}{l}11.11-32 \\
11.11-12,15,30-2\end{array}$ \\
\hline $\begin{array}{l}\text { (6) Cosmic scale } \\
\text { salvation }\end{array}$ & $5.12-21 ; 8.18-23$ & $11.28-32$ \\
\hline (7) Doxology & $8.38-9$ & $11.33-6$ \\
\hline
\end{tabular}

5.18 and the crescendo of 8.39, it may seem that God's wrath has vanished, since 'nothing can separate us from the love of Christ'. But it turns out that 8.39 is not the finale, as Paul in Rom 9 seems to retract his cosmic picture of salvation in Christ and reintroduce some of the characters one thought had been killed off: unbelief, disobedience, exclusion, and then that dreaded word that began the body of the letter, wrath. What has happened ${ }^{53}$ In the microcosmic relation outlined above, Rom 9-11 is Paul's application of Rom 1-8 to Israel.

53 Dodd famously argues that Rom 9-11 'can be read quite satisfactorily without reference to the rest of the epistle', probably as 'a separate treatise' (Romans, 161-2). Dodd does see some 
Just as Paul begins the letter by asserting God's judging wrath upon the world's unrighteousness (1.18), he begins chapters 9-11 by casting some Israelites as reci-

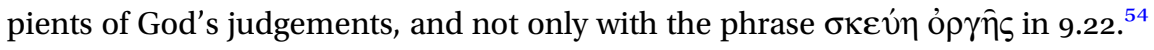
Paul also signals this exclusion by saying it is not the case that 'all Israel is Israel' and by using language of exclusive election in Rom 9 (see especially vv. 6-8, 11$13,15,18,21,30-3)$. The division between God's mercy and judgement is concisely stated in 9.18: God has mercy on whom he pleases, and he hardens whom he pleases. The vessels made for dishonour and wrath rather than honour and mercy in 9.21-2 align with those whom God hardens in 9.18. The picture is bleak. ${ }^{55}$

Furthermore, in Rom 11 Paul envisions God's active judgement even more vividly than in Rom 9. In 11.7 he claims that Israel did not reach what it sought - presumably righteousness or the law of righteousness from 9.31. Israel

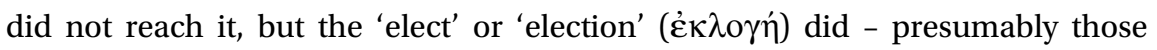
within Israel who are of the election. The 'rest', Paul says in 11.7, were hardened. Then he clarifies that this is a divine passive (see v. 8), as God is the one who actively hardens the rest, i.e. the non-elect according to 11.7. God's judgement further entails giving them a spirit of stupor, eyes that do not see, ears that do

resonance between 9-11 and the rest of the epistle (e.g. 12.1 and 11.30-2) such that 9-11 are not a 'mere interpolation', but he nonetheless regards these chapters as possibly a separate sermon Paul had developed for other occasions (163). As noted above, however, many see the turn to unbelief in Israel as critical to Paul's argument.

54 Pace Hanson, Wrath of the Lamb, 90-1 (and A. T. Hanson, 'Vessels of Wrath or Instruments of

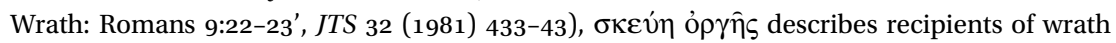
rather than mere instruments of wrath: Pharaoh is an instrument for one purpose but he is a recipient of God's judgement (9.18); the vessels of wrath and mercy parallel the vessels made for dishonour and honour in 9.21 ('use' does not appear); vessels of mercy are prepared

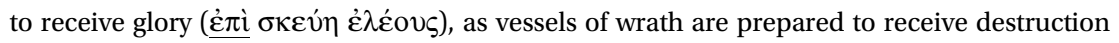

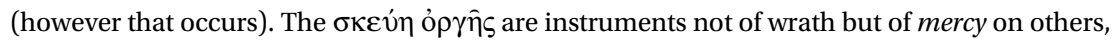
as the iv $\alpha$ clause in 9.23 suggests and the statements in 11.11-12, 15 confirm. As argued below, furthermore, Rom 11 more extensively depicts God's wrath upon (not through) unbelieving Israel.

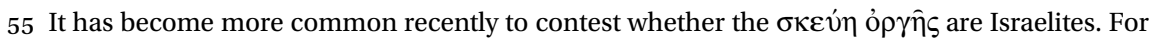
instance, see M. Wolter, "It is Not as though the Word of God Has Failed”: God's Faithfulness and God's Free Sovereignty in Romans 9:6-29', God and Israel: Providence and Purpose in Romans 9-11 (ed. T. D. Still; Waco, TX: Baylor University Press, 2017) 27-47, at 41-2. Wolter is right that Paul's focus here is on God's sovereignty, but Paul is nonetheless grieving those of his flesh (9.3) who are not Israel $(9.6-7,11-13)$. The crisis is that some Israelites are hardened $(9.18 ; 11.7)$, are found at fault $(9.19)$, are made for dishonour $(9.21)$, have not reached righteousness (9.31-2; 11.7), are not now saved (10.1), have not obeyed the gospel

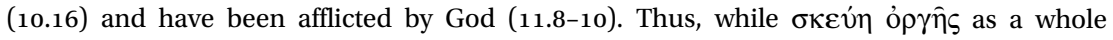
would include gentiles, here and throughout Rom 9-11 Paul focuses on Israelites under God's wrath. 
not hear and darkened eyes, and placing a snare and a stumbling block in their way. This punishment by God in 11.7-10 describes God pouring out his wrath on some of Israel: the non-elect.

Why classify the actions in 11.7-10 as wrath? First, descriptions of divine wrath in Romans do not hinge on the use of the particular word óprí, as wrath, judgement and punishment are closely intertwined and often interchangeable in the

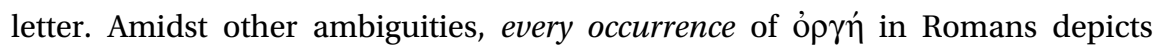
some form of undesirable punishment falling upon human disobedience, none suggesting anyone other than God as the agent. ${ }^{56}$ Furthermore, Paul often uses o $\rho \gamma$ ' and 'judge' terms synonymously to denote God's punitive actions (e.g. $2.2-5 ; 3.5-6 ; 13.2-5)$. Thus, wrath in Romans is judgement that involves punishment in a broad sense. A second reason to classify 11.7-10 as wrath is that in vv. 8-10 Paul cites texts which themselves clearly describe divine judgement: Ps 68 (vv. 23-4 are cited in Rom 11.9-10) even explicitly labels these actions as

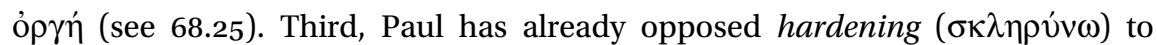
mercy in 9.18, just before he then opposes wrath to mercy in 9.22-3, forging a link between hardening and wrath. Here in 11.7 he applies a similar image of hardening to 'the rest'. Fourth, the picture in 11.7-10 closely resembles Rom 1. People are culpable, but God emerges as the agent who turns people over - in Rom 1 to senseless minds, futile thinking and darkened hearts, and here in Rom 11 to hardening, dullness, blindness and deafness. Hence, both Rom 1 and Rom 11 portray God's judgement in terms of epistemic affliction.

This fourth point signals a pronounced resemblance between the portraits of divine judgement in Rom 1 and Rom 11 (Table 2). This is further confirmation that chapters 9-11 fit with chapters 1-8: Paul is applying the message of Rom 1-8 to Israel, and God's wrath takes similar shape when he hands people over to disobedience.

Part of the message in Rom 1-8, however, is that God's wrath can lead to future mercy. Paul declares in 11.11 that, although God has made these Israelites stumble, this is not done to make them fall. Rather, this punishment is serving a purpose, since by their trespass salvation comes to the gentiles. Then Paul anticipates a further purpose for this gentile inclusion: namely, to make excluded Israel jealous. In the next verse (v. 12) Paul anticipates the full inclusion $(\pi \lambda \eta \rho \omega \mu \alpha)$ of those who now trespass and have been defeated. In 11.15, he assumes that they have indeed been cast away ( $\dot{\alpha} \pi \mathrm{o} \beta \mathrm{o} \lambda \hat{\eta})$, but envisions their acceptance. Thus, in these verses Paul makes clear that God's judgement of exclusion and casting away is not necessarily permanent and does not preclude future

56 Rom 2.5, 8; 3.5; 12.19; and 13.4-5 are revealing examples of why the absence of $\theta \varepsilon 0 \hat{v}$ with

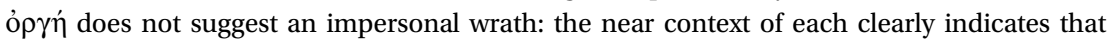
the wrath is God's. 
Table 2. Wrath in Romans 1 and Romans 11

\begin{tabular}{|c|c|}
\hline Romans 1 (all humanity) & Romans 11 (Israel) \\
\hline Problem: & Problem: \\
\hline Do not acknowledge God $(1.21,28)$ & Improper acknowledgment (10.2-3) \\
\hline Considered themselves wise $(1.22)$ & 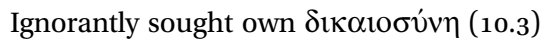 \\
\hline Suppress, disobey truth $(1.18 ; 2.8)$ & Disobedient $(10.16,21 ; 11.30-2)$ \\
\hline Judgement (1.21-8): & Judgement (11.7-10): \\
\hline Senseless minds & Hardened minds/senses \\
\hline Futile thinking & Dysfunctional eyes and ears \\
\hline Darkened, misunderstanding hearts & Darkened eyes \\
\hline Fools & Spirit of stupor/dullness \\
\hline
\end{tabular}

inclusion and salvation. In light of the common image of God's temporary wrath in Paul's scriptures, this should come as no surprise.

After warning the gentiles in his audience not to grow arrogant over these now excluded Jews (v. 18), Paul continues this line in 11.25, telling them that the mystery he is about to reveal should prevent them from being 'wise to yourselves'. This mystery ties back to 11.7, when Paul spoke of the rest (non-elect) being hardened: here in $\mathbf{1 1 . 2 5}$ he continues to describe their plight in similar terms: 'a partial hardening has come upon Israel until the fullness of the gentiles enters, and in this way all Israel will be saved'.

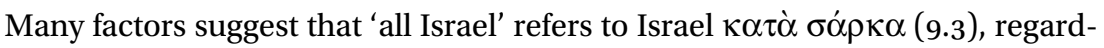

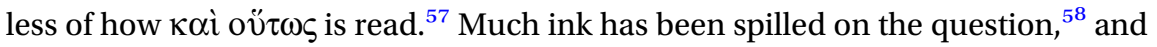
the key points need not be rehashed. What is most germane for the current argument is that Paul has already and repeatedly insisted that God's judgement on those now excluded and hardened does not preclude future salvation (11.11-12, $15-16,23-4)$, and this salvation comes from the same God who has hardened

Whether taken as 'in this way' or 'then' (or as modal or temporal), oü $\tau \omega \varsigma$ could either way refer to the salvation of ethnic Israel (or not). J. R. Wagner interprets it as both consecutive and temporal: 'as a result and subsequent to the entrance of the full number of the Gentiles' (Heralds of the Good News: Paul and Isaiah 'In Concert' in the Letter to the Romans (NovTSup 101; Leiden: Brill, 2002) 279 n. 194; emphasis original). P. van der Horst argues that 'the modal and temporal senses [of oひ̈ $\tau \varsigma$ ] are not necessarily mutually exclusive'

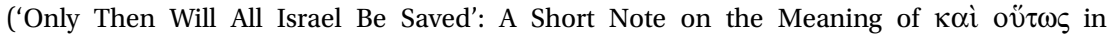
Romans 11.26', JBL 119 (2000) 521-5, at 524).

58 For a thorough review, see C. Zoccali, 'And So All Israel Will Be Saved: Competing Interpretations of Romans 11.26 in Pauline Scholarship', JSNT 30 (2008) 289-318. 
the 'rest' ${ }^{59}$ Furthermore, the mystery is supposed to work against gentile pride (11.25). If the content of the mystery is simply that some Israelites have been hardened for 'you gentiles' to come in, this is precisely what Paul says in 11.19 is an example of misguided boasting: 'You will say then, "Branches were broken off in order that I might be grafted in."' The mystery is that hardened Israel will follow gentiles through the door of salvation: wrath leads to mercy. ${ }^{60}$

The mystery of hardening and wrath leading to salvation addresses the problem that Paul has been tackling since 9.1, namely, what is our supposedly faithful God from chapters 1-8 doing about his promises to Israel? To answer this, Paul admits that some of Israel are not Israel because they do not now believe, and God is sovereign even over this disobedience - just as God is the actor in 1.18-32. God has appointed some as vessels of wrath and some as vessels of mercy. Paul then describes how God works out this judgement on those who are not now in this election: God hardens them, blinds them and deafens them, very much like God's turning over people to darkened hearts and senseless minds in 1.21-2, 28. In 11.25-6, however, Paul asserts that this hardening upon part of Israel only lasts until the full inclusion of the gentiles, and this inclusion of gentiles will be the means by which all Israel is then saved.

One can now step back and see three things that confirm this reading. First, this trajectory resembles the arc of chapters 1-8. What Rom 1-8 describes on a cosmic scale, Rom 9-11 now applies to a specific case. In both cases this arc begins by looking at unbelief and disobedience, then it notes God's wrath at this disobedience, describes God's judging actions of giving people over to disobedient and senseless minds, and explains how those at odds with God and under God's wrath are brought back through God's salvation in all-encompassing language. Second, the pattern of God's wrath leading to God's mercy also resembles a common feature of God's judgement upon Israel in their own traditions:

59 Paul's citations in vv. 26b-27 clarify that the God who hardens is the same God who delivers the rest: see M. Wolter, 'Ein exegetischer und theologischer Blick auf Röm 11.25-32', NTS 64 (2018) 123-42, at 130-6.

60 Rom 11.28 may be the most perplexing verse in the entire letter. Whatever 11.28 means, however, 11.30-1 reinforce the theme: mercy from judgement. One thing that is clear in 11.28 - although it muddies other waters - is that these enemies of the gospel who are 'beloved according to the election' cannot be part of the election in 11.7 that has obtained what hardened Israel did not. Disobedience (v. 30) aligns them with the 'disobedient and contrary people' of 10.21. They are the hardened 'rest', as v. 25 also makes clear. In other words, Paul describes two different 'elections' in 11.7 and 11.28. This is not so shocking, as most inter-

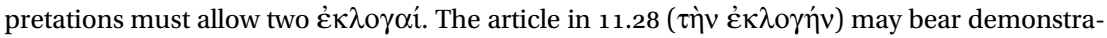
tive force - 'this election', i.e. the covenant (v. 27) just described in 11.25-7 - but that is hard to certify. This division of elections reflects what Wolter calls 'ein Riss durch das Gottesvolk' in 11.1-10 (Wolter, 'Blick auf Röm 11.25-32', 124). For a focused treatment of the puzzle of 11.28, see J. R. Wagner, “Enemies" Yet "Beloved" Still: Election and the Love of God in Romans 9-11', God and Israel: Providence and Purpose in Romans 9-11, 95-113. 
across Paul's scriptures as well as other Jewish literature, God's wrath can be temporary, consonant with mercy and even remedial. Third, this pattern is confirmed by the very last verse of Paul's argument in Rom 9-11 before the doxology: 'God has imprisoned all in disobedience in order that he might have mercy upon all.' Imprisoning in disobedience is what God does in 1.18-32 by turning people over, and this is precisely what God does to disobedient Israel in Rom 11, turning them over to hardening, blindness and deafness. In both cases, this turning over to disobedience is not the end, but rather leads to God's mercy upon all.

Most immediately, Rom 11.32 wraps up Paul's argument from vv. 30-1. 'You gentiles' were disobedient but have now received mercy by Israel's disobedience, and they have been disobedient but will also receive mercy. Disobedience by all moves towards mercy upon all. Furthermore, 11.32 concludes all of chapters 9-11 as well, by summarising the arc of God's punishment upon unbelief that then leads to mercy upon all, i.e. including currently hardened Israel. But 11.32 also culminates all of chapters 1-11. Not only is the trajectory of disobedience to mercy present in 11.30-1 or in chapters 9-11 where part of Israel is disobedient but then will receive mercy, but this is also the trajectory across Rom 1-11. The body of the letter begins with God's wrath upon disobedience, but this wrath is not the end of the story, and salvation comes. Then chapters 9-11 finalise the move from wrath to mercy by answering the pressing question that still prevents one from saying - even at the end of chapter 8 - that God has mercy upon all: 'What about unbelieving Israel?' These Israelites are needed to complete the all. Now that he has answered this question, Paul can stretch back out to the cosmic scale and declare at the end not just of 9-11 but also of 1-11, 'God has imprisoned all in disobedience in order that he might have mercy upon all.'

\section{Conclusion: Marrying Wrath and Mercy}

The range of interpretations aimed at comprehending Paul's argument in Rom 9-11 is as widely disparate as anything in Pauline scholarship. Heikki Räisänen captures the nub of the problem for most: Paul's argument in 9.6-29 is logical and complete even if unsatisfying to some, viz. God's word has not failed because he never promised anything to ethnic Israel. ${ }^{61}$ What follows 9.29, particularly in chapter 11 , is what commentators struggle to square both with 9.6-29 and with chapters 1-8.

61 H. Räisänen, 'Paul, God, and Israel: Romans 9-11 in Recent Research', The Social World of Formative Christianity and Judaism: Essays in Tribute to Howard Clark Kee (ed. J. Neusner et al.; Philadelphia: Fortress, 1988) 178-206, at 184. 
Some claim that Paul is being heavily dialectical, ${ }^{62}$ but Räisänen retorts that 'vage Behauptungen über Dialektik oder Paradoxie' distract from legitimate attempts to interpret the discrepancy in these chapters. ${ }^{63}$ Others believe that Paul changes his meaning for 'Israel' within one sentence, climactically revealing that 'Israel' refers to the body of believers rather than Israelites. ${ }^{64}$ Several have contended that Paul speaks here of two different covenants, whereby gentiles are saved by faith while Israel has a Sonderweg that does not require this allegiance to Christ. ${ }^{65}$ Some even suggest that Paul received a new revelation between Rom 9 and Rom $11 .^{66}$ Before most of these efforts, however, Rudolf Bultmann had already deemed Rom 11 a 'speculative fantasy' of Paul's in which he is driven to hold out hope for historical Israel. ${ }^{67}$ Bultmann's conclusion, followed by many, is that Rom 9 and Rom 11 are completely contradictory. ${ }^{68}$

One root of this dizzying array of readings is a common but misleading presupposition that wrath and mercy are mutually exclusive. On that basis, if Paul speaks of wrath and mercy on Israel, he must be contradicting himself, or dithering in dialectic, or speaking of two covenants or of two Israels. But when the

62 See J. M. Oesterreicher, 'Israel's Misstep and her Rise: The Dialectic of God's Saving Design in Romans 9-11', Studiorum Paulinorum Congressus Internationalis Catholicus 1961 (2 vols.; Rome: E Pontificio Instituto Biblico, 1963) I.317-27; C. Müller, Gottes Gerechtigkeit und Gottes Volk: Eine Untersuchung zu Römer 9-11 (Göttingen: Vandenhoeck \& Ruprecht, 1964) 107-8; E. Käsemann, Commentary on Romans (Grand Rapids: Eerdmans, 1980) 266, 282 and passim.

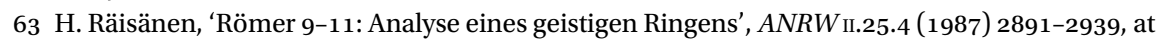
2930.

64 E.g. Thomas Aquinas, Summa Sup. 99.2, ad 2; Calvin, Commentaries on the Epistle of Paul to the Romans (trans. J. Owen; Edinburgh: Calvin Translation Society, 1849) 437; K. Barth, The Epistle to the Romans (trans. E. C. Hoskyns; London: Oxford University Press, 19336 ${ }^{6}$ 45- $^{-}$ 16; N. T. Wright, Paul and the Faithfulness of God (Minneapolis: Fortress, 2013) 1231-52.

65 See Stendahl, Paul among Jews and Gentiles, 4; F. Mussner (who sees this happening at Christ's parousia, but not via conversion), “Ganz Israel wird gerettet werden” (Röm 11,26) Versuch einer Auslegung', Kairos 18 (1976) 241-55; J. Gager, Origins of Anti-Semitism: Attitudes toward Judaism in Pagan and Christian Antiquity (New York: Oxford University Press, 1983) 261-4; L. Gaston, Paul and the Torah (Eugene, OR: Wipf and Stock, 2006) 147-9.

66 B. Noack claims Paul did not receive the inspired knowledge that all Israel would be saved until he was dictating Rom 11 ('Current and Backwater in the Epistle to the Romans', ST 19 (1965) 155-66, at 165). Similarly, without positing inspiration, N. Walter, 'Zur Interpretation von Römer 9-11', ZThK 81 (1984) 172-95, at 176.

67 R. Bultmann, 'Geschichte und Eschatologie im Neuen Testament', Glauben und Verstehen: Gesammelte Aufsätze, vol. III (Tübingen: Mohr Siebeck, $\left.1962^{2}\left[1960^{1}\right]\right)$ 91-106, at 101.

68 R. Bultmann, Theology of the New Testament (trans. Kendrick Grobel; 2 vols.; New York: Scribner's, 1951-5) II.132. J. A. Linebaugh denies that Rom 11 is 'a soteriological sleight of hand' since 'the future Paul promises [to Israel] is patterned by the same unconditioned grace revealed in the christological present and thereby made legible in Israel's Scripture' ('Not the End: The History and Hope of the Unfailing Word in Romans 9-11', God and Israel: Providence and Purpose in Romans 9-11, 141-63, at 159). 
presupposition is removed, the need for these strains collapses. The conviction that wrath and mercy are opposites can be traced through the history of interpretation back at least to Marcion, but Paul's scriptures frequently bear testimony to the contrary. Living in the thought-world of texts such as Isaiah and the Psalms, where so often 'the secret of anger is God's care', ${ }^{69}$ Paul describes a remarkable but not contradictory relationship between God and his people. As with the cosmos, so with Israel: 'On account of my wrath I struck you and on account of my mercy I loved you' (Isa 60.10).

69 Heschel, Prophets, 374. 